\title{
The Rhetorics of Health and Medicine: Inventional Possibilities for Scholarship and Engaged Practice
}

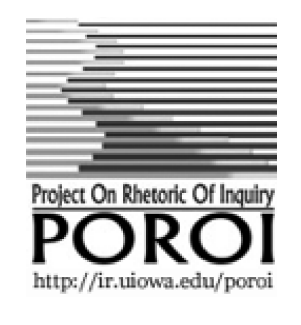

\author{
J. Blake Scott \\ Department of Writing Studies, Central Florida University \\ Orlando, FL USA
}

Judy Z. Segal

Department of English, University of British Columbia

Vancouver, BC Canada

\author{
Lisa Keränen \\ Department of Communication, University of Colorado Denver ${ }^{1}$ \\ Denver, CO USA
}

Poroi 9,1 (April 2013)

Initially an offshoot of scholarship in the rhetoric of science, research concerning what is sometimes called "medical rhetoric," the "rhetoric of medicine," or "biomedical rhetoric" has proliferated in recent years. Rhetoricians can look to an ever-growing set of books (Bennett, 2009; Berkenkotter, 2008; Emmons, 2010; Heifferon, 2005; Heifferon \& Brown, 2009; Hyde \& Herrick, 2013; Keränen, 2010b; Leach \& Dysart-Gale, 2010; Scott, 2003b; Segal, 2005; Wells, 2010), encyclopedia and overview essays (Derkatch \& Segal, 2005; Keränen, 2010a; Segal 2009b), special issues (Barton, 2005; Hass, 2009; Koerber \& Still, 2008; Lyne, 2001; Present Tense Editors, 2012), RSA workshops (held in 2007, 2009, and 2011), and journal articles (Derkatch, 2012; Ding, 2009; Graham, 2009; Keränen, 2011b; Majdik \& Platt, 2012; Owens, 2009; Paroske, 2012; Pender, 2012; Scott, 2006; Segal, 2009a; Spoel \& James, 2006; Teston, 2009) as evidence of growth. In this report, we reflect on the inventional possibilities for future scholarship in the area. We maintain that rhetoricians of health and medicine should continue to carve out an expansive focus on the exigencies, functions, and impacts of health-related discourse; attend to the movement, surrounding networks, and ecologies of this discourse; and work with other scholars/researchers, both inside and outside disciplinary rhetorical studies, toward a variety of goals.

We first advocate that scholars adopt the term rhetorics of health and medicine to signal a broad array of health publics, their nomoi, and their

\footnotetext{
${ }^{1}$ All three authors contributed equally to this report following a conversation at the 2012 ARST preconference with Jessica Eberhard, George Gittinger, Scott Graham, Jennifer Malkowski, and Gina Miller.
} 
discursive practices, some of which only partially intersect with medical institutions. Most global citizens, for example, engage daily with a wide variety of health and wellness texts, technologies, objects, agents, and agencies. Expanding our purview to include the broader set of health texts, artifacts, genres, and practices allows rhetorical scholars interested in medicine and health to address more fully the constellation of symbolic and material rhetorics that influence daily life and public meanings and practice. Expanding our purview should also involve heightened attention to transnational rhetorics of health and medicine with particular focus on the online networks and digital practices that the global citizenry increasingly uses to understand health and medicine.

We also advocate defining the scope of our work by engaging in programs of research that complement, but are different from, programs of research in bioethics, medical humanities, health communication, or the allied health professions. Simply enlisting ourselves in the agendas of others, particularly in a way that reinforces a dichotomy between art and science (see Solomon, 2008), can limit the reach of our contributions. Rather than positioning rhetorical negotiation in opposition to evidencebased medicine, for example, we might ask how the latter's implementation is embedded in the former.

We would do well to stake our scholarly claim in a way that clarifies our unique contributions while encouraging inventive collaboration or the generation of hybrid methods. Examples of work that productively makes this double move include Lisa Keränen's (2011b) recent call for biocriticism, Blake Scott's (2003a) rhetorical-cultural analysis, and Jordynn Jack and Greg Applebaum's (2010) formulation of neurorhetorics. Rhetorics of health and medicine may be seen, in some sense, to be a branch of Medicine Studies (see Paul, 2009) on the model of Science and Technology Studies; its goal is not, in the first instance, to further the aims of medicine as it is, but rather to query medicine's epistemology, culture, principles, practices, and discourses. In so doing, we might consider the generative potential of viral models of rhetorical movement and nuanced models of rhetorical agency that some of us have developed (Scott, 2003b, 2006). In fact, we could model our collaboration after the viruses that some of us study, seeking openings to infect, mutate, and transform larger projects.

In developing our contributions, rhetoricians of health and medicine might think in terms not only of analysis but also of rhetorical techne. How can such techne as rhetorical listening and intercultural inquiry, for instance, improve patient-provider communication and public health interventions, respectively? While rhetoricians of health and medicine may not suggest specific corrections to a flawed system, we do, ultimately, believe our work shares some type of ameliorative aim-perhaps, ultimately, helping to improve medical training, patient-provider interaction, public health efforts, and health literacy. We note that research need not be "applied" in order to be "useful." Segal (2005) distinguishes between applied and useful projects in the rhetorics of health and medicine: for example, "applied" rhetorical research on HIV prevention might produce a book on persuading people to practice safer sex (Perloff, 2001), while research querying the terms and arguments 
through which we understand HIV testing as a cultural practice is useful even if not applied (Scott, 2003b). Setting ameliorative goals requires engaging others in hard questions around, and sometimes disagreeing about, how to determine whether our contributions are beneficial, and for whom.

Any discussion of our goals must be accompanied by questions about how to achieve them. Here, too, rhetoricians might remain open, adapting our methods to the demands and opportunities in our research. Rhetorical studies of health and medicine have increasingly embraced theoretical frameworks and methods that can account for the complexities of language as social action, shifting our focus from texts to the networks, ecologies, and activity systems that shape health-related discourse and its effects. Many rhetoricians of health and medicine are looking beyond traditional rhetorical theory and methods-with their emphases on the persuasive moves of authors in texts-to explore other means of rhetorical inquiry. For instance, rhetoricians have turned towards critical discourse analysis (Fairclough, 2003), actor-network theory (Latour, 2005), and multiple ontologies (Mol, 2003) that foreground interconnectedness, materiality, and movement in health and medicine. Others have augmented their textual analysis with participant observation, interviewing, computer assisted textual analysis, and focus groups in order to access a broader spectrum of participant perspectives (see, e.g., Keränen, 2007; Teston, Graham, Baldwinson, et al., 2013). One challenge in looking beyond the traditional rhetorical toolbox is how to utilize the methods of social science in ways that leverage our uniquely rhetorical contributions.

If our work is to fulfill its aims, it must reach and influence its multiple audiences, which include the range of stakeholders and publics tied to the practices we examine. In some cases, as in Susan Wells' (2010) study of the discursive development of Our Bodies, Ourselves, these stakeholders might be engaged in the research itself. Like forming partnerships with other researchers, reaching the stakeholders of our work may require us to write in registers and forums outside of the academy. We would do well to follow the lead of other colleagues in rhetoric (and many of us already working in the rhetoric of health and medicine) in creating and implementing tactics for engaging publics and policymakers directly. Reaching the stakeholders of health discourse makes our already existing venues for rhetorical scholarship more inviting and accessible.

\section{References}

Barton, E. (Ed.). (2005). Introduction to the special issue on the discourse of medicine. Journal of Business and Technical Communication, 19, 245-248.

Bennett, J. A. (2009). Banning queer blood: Rhetorics of citizenship, contagion, and resistance. Tuscaloosa, AL: University of Alabama Press.

Berkenkotter, C. (2008). Patient tales: Case histories and the uses of narrative in psychiatry. Columbia, SC: University of South Carolina 
Press.

Derkatch, C. (2012). Demarcating medicine's boundaries: Constituting and categorizing in the journals of the American Medical Association. Technical Communication Quarterly, 21, 210-229.

Derkatch, C., \& Segal, J. Z. (2005). Realms of rhetoric in health and medicine. University of Toronto Medical Journal, 83, 138-142.

Ding, H. (2009). Rhetorics of alternative media in an emerging epidemic: SARS, censorship, and extra-institutional risk communication. Technical Communication Quarterly, 18, 327-350.

Emmons, K. (2010). Black dogs and blue words: Depression and gender in the age of self-care. New Brunswick, NJ: Rutgers University Press.

Fairclough, N. (2003). Analysing discourse: Textual analysis for social research. London, UK: Routledge.

Graham, S. S. (2009). Agency and the rhetoric of medicine: Biomedical brain scans and the ontology of Fibromyalgia. Technical Communication Quarterly, 18, 376-404.

Hass, C. (Ed). (2009). Special issue on writing and medicine. Written Communication, 26, 115-211.

Heifferon, B. (2005). Writing in the health professions. New York: Allyn \& Bacon/Longman.

Heifferon, B., \& Brown, S. C. (Eds.). (2009). The rhetoric of healthcare: Essays toward a new disciplinary inquiry. Cresskill, NJ: Hampton Press.

Hyde, M., \& Herrick, J. (Eds). (2013). After the genome: A language for our bioetechnological future. Waco, TX: Baylor University Press.

Jack, J., \& Applebaum, G. (Eds.) (2010). “This is your brain on rhetoric:” Research directions for neuroscience, special issue on neurorhetorics. Rhetoric Society Quarterly, 40, 411-437.

Keränen, L. (2007). 'Cause someday we all die': Rhetoric, agency, and the case of the 'Patient' Preferences Worksheet." Quarterly Journal of Speech, 93, 179-210.

----. (2010a). Rhetoric of medicine. In S. H. Priest (Ed.), Encyclopedia of science and technology communication, Volume 2 (pp. 639-42). Thousand Oaks, CA: Sage.

----. (2010b). Scientific characters: Rhetoric, politics, and trust in breast cancer research. Tuscaloosa, AL: University of Alabama Press.

----. (2011a). Addressing the epidemic of epidemics: Germs, security, and a call for biocriticism. Quarterly Journal of Speech, 97, 224-244.

----.. (2011b). Concocting viral apocalypse: Catastrophic risk and the production of bio(in)security. Western Journal of Communication, 75, 451-472.

Koerber, A., \& Still, B. (Eds). (2008). Guest editor's introduction: Online health communication. Technical Communication Quarterly, 17, 259- 
263.

Latour, B. (2005). Reassembling the social: An introduction to actornetwork-theory. Oxford, UK: Oxford University Press.

Leach, J., and Dysart-Gale, D. (Eds). (2010). Rhetorical questions of health and medicine. Lanham, MD: Lexington Press.

Lyne, J. (Ed). (2001). Contours of intervention: How rhetoric matters to biomedicine, introduction to the special issue on the rhetoric of medicine. Journal of Medical Humanities, 22, 3-13.

Majdik, Z. P., \& Platt, C. A. (2012). Selling certainty: Genetic complexity and moral urgency in Myriad Genetics' BRACAnalysis campaign. Rhetoric Society Quarterly, 42, 120-143.

Mol, A. (2003). The body multiple: Ontology in medical practice. Durham, NC: Duke University Press.

Owens, K. H. (2009). Confronting rhetorical disability: A critical analysis of women's birth plans. Written Communication, 26, 247-272.

Paroske, M. (2012). Overcoming burdens of proof in science regulation: Ephedra and the FDA. Rhetoric and Public Affairs, 15, 467-498.

Paul, N. (2009). Medicine studies: Exploring the interplays of medicine, science and societies beyond disciplinary boundaries. Medicine Studies, 1, 3-10.

Pender, K. (2012). Genetic subjectivity in situ: A rhetorical reading of genetic determinism and genetic opportunity in the biosocial community of FORCE. Rhetoric and Public Affairs, 15, 319-350.

Perloff, R. M. (2001). Persuading people to have safer sex: Applications of social science to the AIDS crisis. Mahwah, NJ: Erlbaum.

Present Tense Editors. (2012). Special double issue on medical, gender, and body rhetorics. Present Tense, 1-2. Accessed April 5, 2013. http://www.presenttensejournal.org

Scott, J. B. (2003a). Extending rhetorical-cultural analysis: Transformations of home HIV testing. College English, 65, 349-67.

----. (2003b). Risky rhetoric: AIDS and the cultural practices of HIV testing. Carbondale, IL: Southern Illinois University Press.

----. (2006). Kairos as indeterminate risk management: The pharmaceutical industry's response to bioterrorism. Quarterly Journal of Speech, 92, 115-143.

Segal, J. Z. (2005). Health and the rhetoric of medicine. Carbondale, IL: Southern Illinois University Press.

----. (2009a). Internet health and the 21st-century patient: A rhetorical view. Written Communication, 26, 351-369.

----. (2009b). Rhetoric of health and medicine. In A. Lunsford, K. H. Wilson, \& R. A. Eberly (Eds.), The SAGE handbook of rhetorical studies (pp. 227-246). Thousand Oaks, CA: Sage. 
Solomon, M. (2008). Epistemological reflections on the art of medicine and narrative medicine. Perspectives in Biology and Medicine, 51, 406-417.

Spoel, P., \& James, S. (2006). Negotiating public and professional interests: A rhetorical analysis of the debate concerning the regulation of midwifery in Ontario, Canada. Journal of Medical Humanities, 27, 167-186.

Teston, C. B. (2009). A grounded investigation of genred guidelines in cancer care deliberations. Written Communication, 26, 320-348.

Teston, C. B., Graham, S. S., Baldwinson, R., Li, A., \& Swift, J. (2013). Public voices in pharmaceutical deliberations: Negotiating "clinical benefit" in the FDA's Avastin Hearing. Journal of Medical Humanities, forthcoming.

Wells, S. (2010). Our Bodies, Ourselves and the work of writing. Palo Alto, CA: Stanford University Press. 